\title{
The Impact of the Disclosure of Non-GAAP Earnings in Australian Annual Reports on Non-Sophisticated Users
}

\author{
Amber Johnson, Majella Percy, Peta Stevenson-Clarke \& Robyn Cameron
}

\section{Summary at a Glance}

This study investigates the impact of non-GAAP earnings disclosure practices on nonsophisticated investors in Australia, given Australia's high investor participation rates, including those operating self-managed superannuation funds. The results show a positive association between the prominent disclosure of non-GAAP earnings information and the reliance of non-sophisticated investors on this information.

The disclosure of non-GAAP earnings in Australian annual reports has risen steadily in recent years. These non-statutory earnings measures are generally disclosed in the unaudited section of the annual report and are not consistent with statutory profit as defined under generally accepted Australian accounting standards (GAAP). Recent research conducted in the United States has provided evidence that non-sophisticated investor decisions are influenced by the presence and prominence of non-GAAP earnings information. Further evidence suggests that investor perception changed after non-GAAP earnings disclosures became subject to regulation in that jurisdiction. Australia has high investor participation rates by international standards, including investors operating self-managed superannuation funds, resulting in a significant number of active individual investors. This study employs an experimental design to investigate the impact on non-sophisticated investors of the reporting of non-GAAP earnings information in addition to GAAP earnings information in Australian annual reports. The results of this study show a positive association between the prominent disclosure of non-GAAP earnings information and non-sophisticated investor reliance on this information. These results provide important evidence to Australian regulators as these narrative disclosures are not subject to regulation, in contrast to the United States where mandatory regulation has been in place since 2003.

Correspondence: Majella Percy, Department of Accounting, Finance and Economics, Griffith University, Nathan, 4111. Tel: (61 7) 3735 4270; fax: (61 7) 3735 3719; email: m.percy@griffith.edu.au 
Many Australian companies disclose non-GAAP (pro forma, non-IFRS or non-statutory) ${ }^{1}$ earnings information in a prominent position in their annual report. Non-IFRS financial information is defined by the Australian Securities and Investment Commission (ASIC) as 'financial information that is presented other than in accordance with all relevant accounting standards' (ASIC 2011: 5). These non-statutory earnings disclosures are a voluntary disclosure generally found in the unaudited narrative section of annual reports, although a small proportion of corporations make these disclosures on the face of the Income Statement ${ }^{2}$.

The international response to a growing trend of prominent disclosure of pro forma earnings has differed from country to country. In December 2011, ASIC released Regulatory Guide 230: Disclosing Non-IFRS Financial Information (RG230), providing guidance on the appropriate use and presentation of non-GAAP earnings information. Notwithstanding, nonGAAP earnings disclosures remain largely unregulated in Australia ${ }^{3}$. In contrast, the United States (US) has had mandatory regulation of non-GAAP disclosures effective since 28 March 2003. The Securities and Exchange Commission (SEC) issued Regulation G and amended Regulation S-K and Form 8-K, resulting in additional requirements on the use of non-GAAP earnings disclosures, including the requirement to lodge earnings releases (under Form 8-K) to the $\mathrm{SEC}^{4}$ (Clark et al. 2003; Nichols et al. 2005). As a result many public companies had to change 'the way they handled non-GAAP disclosures, including earnings releases, earnings calls, SEC filings, and investor conferences' (Clark et al. 2003: 2).

In the US, non-sophisticated investors have been found to rely more on pro forma earnings information than other segments of the market (Bhattacharya et al. 2007). Nonsophisticated investors ${ }^{5}$ often lack task specific knowledge in relation to annual report analysis, resulting in unintentional cognitive effects impacting their decisions and judgments (Coran 2010). Consequently, annual reports that prominently feature non-GAAP earnings information have the potential to significantly influence the decision-making processes of non-sophisticated investors. Further evidence suggests that investor perceptions of non-GAAP earnings in the US changed in the post-regulatory environment (Black et al. 2012). The importance of the regulatory environment can be seen to play a key role in relation to the impact of certain disclosures on the information choice and decision making of investors.

Understanding the impact of non-GAAP earnings disclosures on non-sophisticated investors in an Australian context is important for three reasons. First, localised differences in disclosures practices, coupled with country-specific regulatory environments, logically result in differences in the way these disclosures are perceived by investors. Thus, US findings may 
not necessarily hold in Australia. Second, Australia has high investor participation rates by international standards, including investors operating self-managed superannuation funds (SMSFs), resulting in a significant number of active individual investors, with large values of personal assets at risk (ASX 2010; APRA 2012). Third, research has raised concerns regarding current Australian non-GAAP disclosure practices and their potential to mislead investors (ASIC 2011; Cameron et al. 2012; Sek and Taylor 2011) resulting in regulatory attention from ASIC.

Research to date indicates significant variation in non-GAAP reporting practices internationally (Entwistle et al. 2005; Epping and Wilder 2011). The conclusion drawn by Entwistle et al. (2005) is that these variations 'suggest caution in moving towards a uniform system of regulation'. Logically, differences in disclosure practices coupled with countryspecific regulatory environments (for example, the difference between the regulatory environment in Australia and the US discussed earlier) would lead to differences in the way these disclosures are perceived by investors and how investors incorporate this information into their investment decision-making process. Arguably, US regulation of non-GAAP disclosures in 2003, along with a number of successful high profile SEC prosecutions relating to inappropriate disclosures, would have added credibility to these disclosures. ${ }^{6}$ Therefore, any proposal to regulate non-GAAP earnings disclosures in Australia should be informed not just by local management disclosure practices but also the impact of current practices and regulatory systems on Australian investors.

Capital market participation rates among Australian individual investors are 'high by international standards' with $46 \%$ of the population (approximately 7.26 million) owning shares, either directly and/or indirectly (ASX 2010). In addition, the rise of SMSFs, comprising 30\% of the value of total superannuation in Australia (APRA 2012), means that a number of these non-sophisticated investors are making investment decisions in relation to funds with significant asset values. ${ }^{7}$ Therefore, determining appropriate levels of, and mechanisms for, investor protection are of key importance.

The disclosure of non-GAAP earnings in Australian annual reports has risen steadily over recent years (ASIC 2011; Cameron et al. 2012; KPMG 2011; Sek and Taylor 2011). Empirical evidence relating to Australian non-statutory disclosure practices indicates considerable variation in non-GAAP metric calculation, the types of departures from GAAP over time, and the transparency of reconciliations to statutory net profit, both within firms and between firms, impacting comparability (Cameron et al. 2012; Sek and Taylor 2011). As a 
result, regulators have expressed concerns about current practices and the possible impact on investors. After surveying the disclosure practices of 250 firms over a three year period, ASIC stated that 'a large number of companies need to make significant improvements to disclosures in the interests of better informed investors' (ASIC 2011: 7). In December 2011, ASIC released Regulatory Guide 230: Disclosing Non-IFRS Financial Information (RG230), providing guidance on the appropriate use and presentation of non-GAAP earnings information.

The prevalence and prominence of pro forma earnings disclosures made by Australian companies, combined with the lack of regulation and the significant levels of capital market participation by non-sophisticated investors, suggest the need for an investigation into the impact of these non-GAAP earnings disclosures. The objective of this study is to conduct an experiment ${ }^{8}$ to determine whether the disclosure of non-GAAP earnings, in addition to GAAP earnings, significantly influences the information choices of non-sophisticated users of Australian annual reports.

The results of this study show a positive association between the prominent disclosure of non-GAAP earnings information and the reliance by non-sophisticated investors on this information. That is, when non-GAAP earnings information is provided, participants tend to select this information rather than GAAP information when asked to identify basic profitability measures such as current year profit, movement in profit and earnings per share from an annual report extract. Thus, despite the lack of mandatory regulation in relation to non-GAAP earnings disclosures in Australian annual reports, these disclosures are incorporated in the information gathering stage of the decision-making processes of nonsophisticated investors.

The contributions of this article are twofold. First, it adds to the growing body of research relating to the increasing trend of reporting non-GAAP earnings. This study contributes by specifically examining the impact of non-GAAP earnings disclosures as they commonly appear in Australian annual reports. Second, the results of this study contribute to the policy debate on non-GAAP earnings disclosures by Australian corporations and the adequacy of investor protection within Australian capital markets. The quality of nonstatutory disclosures by Australian corporations and the potential negative impact on investors is a key concern of regulators. Although there are some Australian studies of aspects of nonGAAP disclosures (Cameron et al. 2012; Sek and Taylor 2011; Malone et al. 2012), this is the 
first Australian study to examine the impact of these disclosures on the information choices of investors.

\section{Background and Literature Review}

The disclosure of non-GAAP earnings in Australian annual reports has risen steadily over recent years (ASIC 2011; Cameron et al. 2012; Sek and Taylor 2011), with 82\% of ASX100 companies disclosing non-statutory earnings in their 2011 results (KPMG 2011). Empirical evidence relating to Australian non-statutory disclosure practices indicates considerable variation in pro forma earnings disclosures, with no consistency in the calculation of nonGAAP financial measures or in their reconciliation to statutory net profit (Cameron et al. 2012; Sek and Taylor 2011). This research also reports significant temporal variation in the types of departures from GAAP, both within firms and between firms, impacting comparability. A lack of transparency is also an issue. Cameron et al. (2012) report significant disparity in practice, ranging from highly transparent reconciliations to what appears to be considerable secrecy. They state that 'in some cases only the most diligent of nonsophisticated investors would be aware that the pro forma earnings figure focused on could be considerably different from the statutory net profit' (Cameron et al. 2012:19).

Existing non-GAAP disclosure research, mainly focusing on US firms, finds mixed results in addressing the question of what motivates these disclosures. Lougee and Marguardt (2004) find that firms with less informative GAAP earnings are more likely to report pro forma earnings, suggesting that pro forma earnings are a quality, value relevant metric. Bowen et al. (2005) find that the metrics that firms highlight are more value relevant and illustrate favourable firm performance. Doyle et al. (2003) examine the informational properties of pro forma earnings, finding that higher levels of exclusions lead to lower future cash flows, thereby indicating a negative association between exclusions and future firm value. Marques (2010) reports that managers strategically give more prominence to nonGAAP measures than to GAAP figures when the GAAP number falls short of a benchmark but the non-GAAP earnings number does not. According to Marques (2010: 119), 'this disclosure strategy may influence the perception of the firm's financial results'. As well, Jennings and Marques (2011) provide evidence that prior to Regulation G, but not after it, investors were misled by disclosures of pro forma financial earnings. 
Bhattacharya et al. (2003) investigate market perceptions of pro forma earnings and find that they are perceived as more informative and permanent than GAAP earnings and are more representative of firms' core earnings. Allee et al. (2007) confirm the findings of Bhattacharya et al. (2003), employing an archival methodology using trade size ${ }^{9}$ as a proxy for investor sophistication. They demonstrate that the existence and positioning of pro forma earnings influences the judgments of non-sophisticated investors but not the judgments of sophisticated investors.

There are numerous studies that indicate improved pro forma earnings disclosure practices in the US post Regulation G. Several papers report a reduction in the use of nonGAAP earnings and a decline in the opportunistic use of the earnings metric (Entwistle et al. 2006; Heflin and Hsu 2008). In relation to the pro forma earnings emphasis decision, Bowen et al. (2005) report a highly significant shift away from non-GAAP earnings emphasis toward GAAP earnings emphasis following the implementation of regulation. They find that firms exposed to greater media coverage were more likely to reduce pro forma earnings emphasis and increase GAAP earnings emphasis, providing evidence that increased scrutiny alters the costs and benefits faced by firms making the 'emphasis' decision.

Zhang and Zheng (2011) examine the valuation impact of non-GAAP disclosures in the post-regulatory environment, concluding that high reconciliation quality ${ }^{10}$ (demonstrated by tabular reconciliation of non-GAAP earnings to GAAP earnings in an earnings release) mandated by Regulation $G$ reduces the extent of security mispricing by investors, thus highlighting the positive impact of regulating high quality reconciliations. Black et al. (2012) measure market reactions to earnings announcements and find that investor perception of nonGAAP earnings in the US changed in the post-regulatory environment with investors discounting potentially misleading non-GAAP disclosures in the post-regulatory period. Jennings and Marques (2011) also provide evidence that prior to Regulation G, but not after it, investors were misled by disclosures of pro forma financial earnings.

Examining the impact of non-GAAP disclosures in the US, Elliott (2006) and Frederickson and Miller (2004) find that non-sophisticated investor decisions are influenced by the presence and, in particular, the prominence of pro forma earnings. Both papers suggest that this impact is caused by unintentional cognitive effects rather than the perceived informative value of the earnings information. Elliot (2006) demonstrates that this influence is moderated by the presence of a tabular, quantitative reconciliation of pro forma earnings measures to GAAP earnings measures. 
Psychological research has demonstrated that format and presentation affect the way information is used. Much of the presentation research indicates that investors' judgments and decisions are affected by the placement of information in the financial statements (Trotman et al. 2011). This research also demonstrates that, with appropriate disclosures and presentation formats, the cognitive limitations of investors and analysts can be avoided. Logically the impact of presentation would also apply to the disclosure of pro forma information in the narrative section of annual reports. Presentation of non-GAAP information will be affected by country-specific regulatory environments as well as firm specific disclosure decisions.

A cross-country comparison of pro forma earnings disclosure practices in the US and Canada by Entwistle et al. (2005) finds significant differences between the two countries with managers in the US being more likely to report pro forma earnings and place greater emphasis on them. The results highlight that 'management disclosure decisions can differ significantly even when countries have similar business environments and financial regulations' (Entwistle et al. 2005: 16). Epping and Wilder (2011) compare the disclosure practices of US and US listed foreign firms, presenting some evidence that US firms exhibit non-GAAP disclosure behaviour that is more aggressive as compared to US listed foreign firms. They comment that country-specific investor protection and regulatory environments are likely to 'affect management's choice to use non-GAAP disclosures in a strategic manner' (Epping and Wilder 2011: 94). This research supports the notion that localised differences in disclosure practices would result in differences in the way non-GAAP disclosures are perceived by investors and in turn warrant country-specific regulatory responses to address these disclosures.

Overall, while the existing literature presents mixed findings on the relative usefulness of GAAP versus non-GAAP earnings information, it nevertheless highlights the potential for non-GAAP earnings disclosures to be interpreted differently by non-sophisticated versus sophisticated investors, particularly in an environment where such disclosures are unregulated.

\section{Hypothesis Development}

The objective of this article is to investigate the impact on non-sophisticated report users of disclosing pro forma information in a prominent position in the narrative section of corporate annual reports. In the Australian context, pro forma information is generally disclosed in the 
unaudited narrative section of a corporation's annual report, affording management a significant amount of discretion in relation to how they present this information. Evidence exists that format and presentation affect the way information is used (Trotman et al. 2011), with the positioning and order of information impacting information processing, regardless of the importance of the information. Elliott (2006) finds that non-sophisticated US investor decisions are particularly influenced by the prominence of non-GAAP earnings, caused by unintentional cognitive effects and not the perceived informative value of the earnings information. This gives rise to the research question, does the disclosure of non-GAAP earnings in addition to GAAP earnings significantly influence the perceptions of firm performance and profitability formed by non-sophisticated Australian annual report users?

If non-sophisticated annual report users are influenced by pro forma earnings information reported in addition to GAAP earnings, then the provision of this information could affect their understanding of company performance and profitability. The experiment used in this study requires participants presented with either GAAP earnings information or both GAAP and pro forma earnings information to identify basic earnings items such as profit and earnings per share. Their information choices will arguably reflect their understanding of company performance and profitability, and are expected to vary according to whether or not they are presented with non-GAAP earnings disclosures. Our expectation is that the provision of non-GAAP information in a prominent position within the annual report will result in nonsophisticated investors being more likely to rely on non-GAAP rather than GAAP earnings information in the information gathering stage of assessing company performance and profitability. This gives rise to the following testable hypothesis:

$<$ listing $>$

Hypothesis: There is a positive association between the prominent disclosure of non-

GAAP earnings information and the reliance by non-sophisticated annual report users on non-GAAP earnings information rather than GAAP earnings information when identifying earnings metrics.

$</$ listing $>$

\section{Research Design}

\section{Experimental design}


The approach adopted in this study is a simple $1 \times 2$ between-subjects experiment. The manipulation involved the provision of non-GAAP earnings information in addition to GAAP earnings information versus the provision of GAAP information only. The experiment involved the administration of two different sets of information (treatments) to participants. Participants were randomly assigned either a GAAP earnings treatment or a pro forma earnings treatment whereby they were presented with a case study that included varying combinations of information items typically found in Australian annual reports.

Participants were asked to review the case study content that they had been assigned and then complete a questionnaire based on the information provided. Participants were required to demonstrate their understanding of the earnings information presented in the case study by identifying specific earnings metrics such as profit and earnings per share.

The two treatments were designed to incorporate the types of earnings information Australian companies disclose in their annual reports, albeit in simplified format. The presence of pro forma earnings information in addition to GAAP earnings information varied depending on the treatment administered.

Treatment 1, the GAAP earnings treatment (hereafter GAAP treatment), contained general company information and a GAAP income statement. The GAAP earnings information disclosed a significant decrease in statutory profit (a statutory loss of \$1120 million compared to a \$250 million statutory profit the previous year) and EPS of 12.9c (compared to 2.0c the previous year).

Treatment 2, the pro forma treatment (hereafter PF treatment), contained general company information followed by additional non-GAAP disclosures and a GAAP income statement. The non-GAAP earnings information disclosed an increase in operating profit (an operating profit of \$408.1 million compared to \$258.5 million the previous year) and EPS of 17.4c.

The pro forma earnings information contained in the PF treatment case study material was presented in a format modelled on actual non-GAAP disclosures in Australian annual reports. The aim was to ensure that the case study material was consistent with current Australian annual report disclosure practices. KPMG's Underlying Profits Report (2011) indicates only $9 \%$ of companies disclose non-GAAP earnings on the face of the income statement, therefore the majority of these disclosures are in the narrative section of annual 
reports. Given this current practice, the company in the case study material for the experiment discloses pro forma earnings in the narrative section of the annual report extract.

Research conducted by Cameron et al. (2012) provides evidence of Australian nonGAAP earnings disclosure practices for the period 2007 to 2009. They report that $60 \%$ of these disclosures were emphasised in preference to the statutory net profit, with emphasised non-GAAP disclosures typically exhibiting a better year-on-year trend than statutory net profit. They also report an increasing number of companies emphasising positive non-GAAP earnings in instances of negative GAAP earnings. Therefore, to reflect current practice, the company in the case study material for the experiment reports positive non-statutory earnings but negative GAAP earnings.

\section{Participants}

In relation to participant choice in experimental studies, Trotman (1996: 95) states 'it is vital that subjects with the appropriate level of experience are used' and it is crucial 'to match the task with the appropriate level of experience'. Furthermore, Liyanarachchi and Milne (2005:121) compared the investment decisions of students and accounting practitioners, finding that the short- and long-term investment decisions of students 'compare well with those of the practitioners'. The task set in this experiment is not as complicated as an investment decision, but rather involves the simple task of identifying basic earnings information from an information set. Therefore, given the nature of the task set and the nature of non-sophisticated investors, the participants used in this study were undergraduate accounting students with varying levels of accounting and finance knowledge.

Descriptive statistics for sample participants are presented in Table $\underline{1}$. A total of 156 students participated and were randomly assigned either an information set of a GAAP treatment or a PF treatment, resulting in 88 participants receiving the GAAP treatment and 68 participants receiving the PF treatment. The age of the participants ranged from 18 to 53 with a mean age of 25.65. Participants had completed on average 3.83 accounting subjects and 4.53 finance subjects.

\section{Dependent variables}

The data collected from the questionnaire gave rise to three main variables to examine participant information choice. Participants were asked three main questions. 
1. What is the profit (loss) figure for the current financial year (ending 30 June 2010) for the group?

2. Is there an increase or decrease in profit (loss) from the previous financial year to the current financial year (ending 30 June 2010) for the group?

3. What is the earnings per share (hereafter EPS) figure for the current financial year (ending 30 June 2010) for the group?

The responses provided by participants were placed in one of two categories: (1) the participant provided a response based on GAAP information contained in the case study; or (2) the participant provided a response based on non-GAAP earnings information contained in the case study. This resulted in the following three dichotomous variables: (1) Profit Identification; (2) Change in Profit; and (3) EPS Identification. Figure 1 provides a summary of the experiment design and expected results.

The hypothesis predicts that there is a positive association between the prominent disclosure of non-GAAP earnings information and the reliance of non-sophisticated annual report users on non-GAAP earnings information rather than GAAP earrings information. It is expected that if the hypothesis is supported the results will show that the mean coded GAAP treatment responses will be significantly lower than the mean coded PF treatment responses (Cell $1<$ Cell 2). This result would indicate that the provision of non-GAAP information in a prominent position within the annual report resulted in non-sophisticated investors being significantly more likely to rely on non-GAAP (coded 2) rather than GAAP earnings information (coded 1) when identifying basic earnings metrics.

\section{Results}

\section{Descriptive statistics}

Table $\underline{2}$ shows the correlation matrix between the treatment administered and the three main variables: Profit Identification, Change in Profit and EPS Identification. The results show that there is a significant correlation between the treatment administered and Profit Identification $(p=.001)$, Change in Profit $(p=.000)$ and EPS Identification $(p=.000)$. This result indicates that the different information sets had a significant effect on the way participants responded to the questions, that is, whether participants provided a response based on GAAP earnings 
information (coded 1) or on non-GAAP earnings information (coded 2). The correlations between these variables will be explored further using univariate tests.

\section{Univariate tests}

The univariate tests used to examine the variables in this study are the Independent $t$-test and chi-square test. The $t$-test results for the Profit Identification, Change in Profit and EPS Identification variables compared according to the treatment administered are presented in Table $\underline{3}^{11}$ The mean coded responses of participants receiving the PF treatment ${ }^{12}$ is significantly higher than the mean coded responses of the participants receiving the GAAP treatment (Cell $1<$ Cell 2). The $t$-test results show that the difference between the mean participant responses for the two treatment groups is significant $(p=.000)$. This result indicates that the different information sets significantly influenced the type of earnings information (GAAP or non-GAAP) the two groups of participants identified from the case study material provided.

A chi-square test has been employed to determine whether the observed frequencies (counts) of the categorised responses across the two treatments differ markedly from the frequencies that would be expected to occur by chance. Tables $\underline{4}, \underline{5}$ and $\underline{6}$ present the chisquare test results for Profit Identification, Change in Profit and EPS Identification. The chisquare test results for Profit Identification, Change in Profit and EPS Identification are all significant $(p=.000)$, indicating that the deviation of the actual participant response frequencies between the two treatment groups could not have occurred by chance. As expected, the frequency of non-GAAP responses from participants receiving the PF treatment is significantly higher than the frequency of non-GAAP responses from the participants receiving the GAAP treatment (Cell $1<$ Cell 2). This result indicates that there is a positive association between the prominent disclosure of non-GAAP earnings information and the reliance of non-sophisticated annual report users on non-GAAP earnings information rather than GAAP earnings information.

The results of this experiment demonstrate that the disclosure of additional non-GAAP earnings information significantly impacted the information choices of participants, with participants being more likely to choose non-GAAP earnings figures rather than GAAP earnings figures when asked to identify basic metrics such as current period profit and earnings per share. The participants who received the additional non-statutory earnings information appeared to focus on the prominently positioned pro forma earnings disclosures 
when gathering earnings information from the annual report extract, rather than examining the full range of information provided which included the Income Statement.

\section{Concluding Comments}

The disclosure of non-GAAP earnings in Australian annual reports has risen steadily in recent years (ASIC 2011; KPMG 2011, Cameron et al. 2012; Sek and Taylor 2011). Understanding the impact of non-GAAP earnings disclosures on non-sophisticated investors in an Australian context is important for three reasons. First, localised differences in disclosures practices, coupled with country-specific regulatory environments, logically results in differences in the way these disclosures are perceived by investors. Second, Australia has high investor participation rates by international standards including investors operating self-managed superannuation funds (SMSFs), resulting in a significant number of active individual investors, with large values of personal assets at risk (ASX 2010; APRA 2012). Third, research has raised concerns regarding current Australian non-GAAP disclosure practices and their potential to mislead investors (ASIC 2011; Cameron et al. 2012; Sek and Taylor 2011) resulting in regulatory attention from ASIC.

The objective of this study was to investigate the impact on non-sophisticated investors of prominent disclosures of non-GAAP earnings made by Australian companies in their annual reports. This examination utilised an experimental design where the manipulation involved the provision of non-GAAP earnings information in addition to GAAP earnings information versus the provision of GAAP information only.

The results of the experiment demonstrate that the provision of additional non-GAAP earnings disclosures significantly impacted the information choices of participants. The participants appeared to focus on the prominently positioned non-GAAP earnings disclosures when gathering earnings information from the annual report extract, rather than examining the full range of information provided, which included the Income Statement. If investors' information choices reflect their understanding of company performance and profitability, then this study's findings suggest that the disclosure of non-GAAP information in Australian annual reports is likely to have a significant impact on the opinions formed by nonsophisticated investors regarding company financial performance and profitability.

The contributions of this article are twofold. First, this article adds to the growing body of research relating to the increasing trend of reporting non-GAAP earnings, by being 
the first Australian study to examine the impact of these disclosures on the information choices of investors. Second, the results of this article contribute to the policy debate on nonGAAP earnings disclosures by Australian corporations and the role regulators play in ensuring the adequacy of investor protection within Australian capital markets.

The impact of pro forma disclosures contained in Australian annual reports is of concern to ASIC, industry bodies and accounting professionals. The prevalence of these disclosures demonstrates that they are considered relevant to decision makers by Australian company managers. Given the release of RG230, the attention afforded Australian non-GAAP disclosures is likely to continue to increase. The results of this study regarding the impact of current non-statutory disclosure practices on Australian non-sophisticated investors are therefore likely to be of interest to a wide variety of parties.

As with all experimental studies, there are some limitations to this analysis. The experiments took place in a laboratory setting, with time constraints that meant that case study information and questionnaire length had to be limited. In a real life setting, non-sophisticated annual report users would have considerably more information available to them and would also be free to spend considerably more time analysing that information.

Amber Johnson, Majella Percy and Robyn Cameron are at Griffith University. Peta Stevenson-Clarke is at RMIT Melbourne. They wish to acknowledge the financial support of CPA Australia and the helpful comments and assistance of Jenny Stewart, James Frederickson, Ken Trotman, Thu Phuong Truong and the participants at the 2012 AFAANZ conference in Melbourne.

\section{Notes $<$ endnote_ti $/>$}

\section{References}

Allee, K.D., Bhattacharya, N., Black, E.L and Christensen, T.E. 2007, 'Pro Forma Disclosure and Investor Sophistication: External Validation of Experimental Evidence Using Archival Data', Accounting, Organisations and Society, 32: 20122.

\section{Australian Prudential Regulation Authority, 2012, 'Statistics Quarterly Superannuation}

Performance', December (issued 21 February 2013). Available at 
http://www.apra.gov.au/Super/Publications/Documents/Dec-2012-Quarterly-

Superannuation-Performance-publication.pdf.

Australian Institute of Company Directors and Financial Services Institute of Australasia.

2009, Policy Guidance Paper: Underlying Profit, Principles for Reporting of Non-

Statutory Profit Information.

Australian Securities and Investments Commission, 2011, Regulatory Guide 230 Disclosing

Non-IFRS Financial Information. Available at

http:/www.asic.gov.au/asic/pdflib.nsf/LookupByFileName/rg230-published-9-

december-2011.pdf/\$file/rg230-published-9-december-2011.pdf:

Australian Securities and Investment Commission, 2010, 10-282AD ASIC's review of 30

June 2010 financial reports and focuses for 31 December. Available at

http://www.asic.gov.au/asic/pdflib.nsf/LookupByFileName/Attachment-to-10-

282AD.pdf/\$file/Attachment-to-10-282AD.pdf.

Australian Securities Exchange, 2011, 2010 Australian Share Ownership Study. Available at http://www.asx.com.au/documents/resources/2010_australian_share_ownership_stud y.pdf.

Bhattacharya, N., Black, E.L., Christensen, T.E. and Larson, C.R. 2003, ‘Assessing the Relative Informativeness and Permanence of Pro Forma Earnings and GAAP

Operating Earnings', Journal of Accounting and Economics, 36: 285-319.

Bhattacharya, N., Black, E.L., Christensen, T.E.] and Mergenthaler, R.D. 2007, 'Who Trades on Pro Forma Earnings Information?' The Accounting Review, 82 (3): 581-619.

Black, D., Black, E., Christensen, T. and Heninger, W. 2012, 'Has the Regulation of Pro Forma Reporting in the US Changed Investors' Perceptions of Pro Forma Earnings Disclosure?’ Journal of Business Finance \& Accounting, 39 (7 \& 8): 876-904.

Bowen, R., Davis, A. and Matsumoto, D. 2005, ‘Emphasis on Pro Forma versus GAAP Earnings in Quality Press Releases: Determinants, SEC Intervention, and Market Reactions', The Accounting Review, 80 (4): 1011-38.

Cameron, R., Percy, M. and Stevenson-Clarke, P. 2012, 'Do Large Australian Companies Emphasise Non-GAAP Financial Measures Over Statutory Net Profit (GAAP) In Annual Reports?' JASSA The Finsia Journal of Applied Finance, 1: 19-25.

Clarke, D., Sassalos, P. and Schmitt, K. 2003, 'The SEC’s New Disclosure Requirements for Non-GAAP Financial Information', Insights; the Corporate \& Securities Law Advisor, 17 (4): 2-8. 
Coran, P.J. (2010), 'The Effect of Investor Sophistication on the Influence of Nonfinancial Performance Indicators on Investors’ Judgments', Accounting and Finance, 50: 26380.

Doyle, J., Lundholm, R. and Soliman, M. 2003, 'The Predictive Value of Expenses Excluded from “Pro Forma” Earnings', Review of Accounting Studies, 8 (2-3): 145-74.

Elliott, W. 2006, 'Are Investors Influenced by Pro forma Emphasis and Reconciliations in Earnings Announcements?’ The Accounting Review, 81 (1): 113-33.

Entwistle, G., Feltham, G. and Mbagwu, C. 2005, ‘The Voluntary Disclosure of Pro Forma Earnings: A U.S.-Canada Comparison', Journal of International Accounting Research, 4 (2): 1-23.

Entwistle, G., Feltham, G.) and Mbagwu, C.] 2006, 'Misleading Disclosure of Pro Forma Earnings: An Empirical Examination', Journal of Business Ethics, 69: 355-72.

Francis, J., Nanda, D. and Olsson, P. 2008, 'Voluntary Disclosure, Earnings Quality and Cost of Capital', Journal of Accounting Research, 46 (1): 53-99.

Frederickson, J.! and Miller, J. 2004, ‘The Effects of Pro Forma Earnings Disclosures on Analysts' and Nonsophisticated Investors' Equity Valuation Judgments', The Accounting Review, 79 (3): 667-86.

Heflin, F. and Hsu, C. 2008, ‘The Impact of the SEC’s Regulation of Non-GAAP Disclosures', Journal of Accounting and Economics, 46: 349-65.

Jennings, R. and Marques, A. 2011, 'The Joint Effects of Corporate Governance and Regulation on the Disclosure of Manager-adjusted Non-GAAP Earnings in the US', Journal of Business Finance and Accounting, 38 (3-4): 364-94.

Koonce, L. and Mercer, M. 2005, Using Psychology Theories in Archival Financial Accounting Research. Journal of Accounting Literature, 24: 175-214.

KPMG. 2011, 'Underlying Profits Report'. Available at http://www.kpmg.com/AU/en/IssuesAndInsights/ArticlesPublications/underlyingprofits-report/Documents/underlying-profits-report-2011.pdf.

Liyanarachchi, G. and Milne, M. 2005, 'Comparing the Investment Decisions of Accounting Practitioners and Students: An Empirical Study on the Adequacy of Student Surrogates', Accounting Forum, 29, 121-35.

Lougee, B. and Marguardt, C. 2004, 'Earnings Informativeness and Strategic Disclosure: An Empirical Examination of “Pro Forma” Earnings', The Accounting Review, 79 (3): 769-95. 
Malone, L., Tarca, A. and Wee, M. 2012, 'IFRS and Pro Forma Earnings Disclosures: Determinants and Consequences', Working Paper, University of Western Australia.

Marques, A. 2010, 'Disclosure Strategies Among S\&P 500 Firms: Evidence on the Disclosure of Non-GAAP Financial Measures and Financial Statements in Earnings Press Releases', British Accounting Review, 42: 119-31.

Nichols, N., Gray, S. and Street, D. 2005, 'Pro Forma Adjustments to GAAP Earnings: Bias, Materiality and SEC Action', Research in Accounting Regulation, 18: 29-52.

Sek, J., and Taylor, S. 2011, 'Profit or Prophet? A Case Study of the Reporting of NonGAAP Earnings by Australian Banks', Australian Accounting Review, 59 (21), 4: 327-39.

Trotman, K. 1996, 'Coopers \& Lybrand Accounting Research Methodology Monograph No. 3: Research Methods for Judgment and Decision Making Studies in Auditing', Victorian Printing, Blackburn, Australia.

Trotman, K., Tan, H. and Ang, N! 2011, 'Fifty-year Overview of Judgment and Decisionmaking Research in Accounting', Accounting and Finance, 51: 278-360.

White, A. 2013, 'ASIC flags growth of SMSF'. Available at http://www.theaustralian.com.au/business/financial-services/wise-up-or-risk-legalaction-says-asic/story-fn91wd6x-1226605259944

Zhang, H. and Zheng, L. 2011, 'The Valuation Impact of Reconciling Pro Forma Earnings to GAAP Earnings’, Journal of Accounting and Economics, 51: 186-202.

Figure 1 Summary of experiment design and hypothesis

${ }^{\mathrm{a}}$ The GAAP treatment case study material consisted of general company information and a GAAP income statement.

$\mathrm{b}$ The pro forma treatment case study material consisted of general company information followed by additional pro forma earnings disclosures and a GAAP income statement. The acronym PF treatment is used in reference to this treatment.

Table 1 Descriptive statistics for sample participants

\begin{tabular}{|c|c|c|c|}
\hline & GAAP Treatment $^{a}$ & PF Treatment ${ }^{\mathrm{b}}$ & Combined Sample \\
\hline & $n=88$ & $n=68$ & $n=156$ \\
\hline & Mean & Mean & Mean \\
\hline Age & 25.53 & 25.73 & 25.65 \\
\hline $\begin{array}{l}\text { Accounting subjects } \\
\text { completed }\end{array}$ & 3.26 & 4.49 & 3.83 \\
\hline
\end{tabular}




\begin{tabular}{|l|l|l|l|}
\hline $\begin{array}{l}\text { Finance subjects } \\
\text { completed }\end{array}$ & 3.68 & 5.51 & 4.53 \\
\hline & Percentage (\%) & Percentage (\%) & Percentage (\%) \\
\hline Male & 36.6 & 55.4 & 44.9 \\
\hline Female & 63.4 & 44.6 & 55.1 \\
\hline
\end{tabular}

${ }^{a}$ The GAAP treatment case study material consisted of general company information and a GAAP income statement.

${ }^{b}$ The pro forma treatment case study material consisted of general company information followed by additional pro forma earnings disclosures and a GAAP income statement. The acronym PF treatment is used in reference to this treatment.

Table 2 Correlation of variables

\begin{tabular}{|c|c|c|c|c|c|}
\hline & & $\begin{array}{l}\text { Treatment } \\
\left(\mathrm{GAAP}^{\mathrm{a}} \text { or }\right. \\
\left.\mathrm{PF}^{\mathrm{b}}\right)\end{array}$ & $\begin{array}{l}\text { Profit } \\
\text { Identification }\end{array}$ & Change in Profit & $\begin{array}{l}\text { EPS } \\
\text { Identification }\end{array}$ \\
\hline \multirow{3}{*}{$\begin{array}{l}\text { Treatment } \\
\left(\mathrm{GAAP}^{\mathrm{a}} \text { or }\right. \\
\left.\mathrm{PF}^{\mathrm{b}}\right)\end{array}$} & $\begin{array}{l}\text { Pearson } \\
\text { Correlation }\end{array}$ & 1 & $.386^{* * *}$ & $.456^{* * *}$ & $.515^{* * *}$ \\
\hline & Sig. (2-tailed) & 156 & .000 & .000 & .000 \\
\hline & $N$ & & 153 & 127 & 148 \\
\hline \multirow[t]{3}{*}{$\begin{array}{l}\text { Profit } \\
\text { Identification }\end{array}$} & $\begin{array}{l}\text { Pearson } \\
\text { Correlation }\end{array}$ & $.386^{* * * *}$ & 1 & $.716^{* * *}$ & $.551^{* * *}$ \\
\hline & Sig. (2-tailed) & .001 & 153 & .000 & .001 \\
\hline & $N$ & 153 & & 126 & 147 \\
\hline \multirow[t]{3}{*}{ Change in Profit } & $\begin{array}{l}\text { Pearson } \\
\text { Correlation }\end{array}$ & $.456^{* * *}$ & $.716^{* * *}$ & 1 & $.768^{* * *}$ \\
\hline & Sig. (2-tailed) & .000 & .000 & 127 & .000 \\
\hline & $N$ & 127 & 126 & & 124 \\
\hline \multirow[t]{3}{*}{$\begin{array}{l}\text { EPS } \\
\text { Identification }\end{array}$} & $\begin{array}{l}\text { Pearson } \\
\text { Correlation }\end{array}$ & $.515^{* * *}$ & $.551^{* * *}$ & $.768^{* * * *}$ & 1 \\
\hline & Sig. (2-tailed) & .000 & .001 & .000 & 148 \\
\hline & $N$ & 148 & 147 & 124 & \\
\hline
\end{tabular}

${ }^{\text {a }}$ The GAAP treatment case study material consisted of general company information and a GAAP income statement. 
${ }^{b}$ The pro forma treatment case study material consisted of general company information followed by additional pro forma earnings disclosures and a GAAP income statement. The acronym PF treatment is used in reference to this treatment.

* Correlation is significant at the 0.10 level (2-tailed)

**Correlation is significant at the 0.05 level (2-tailed).

*** Correlation is significant at the 0.01 level (2-tailed).

Table 3 Descriptive statistics for dependent variables

\begin{tabular}{|c|c|c|c|c|c|c|c|c|c|}
\hline & \multicolumn{3}{|c|}{$\begin{array}{l}\text { [spanname="2to } 4 \text { "] GAAP } \\
\text { Treatment }\end{array}$} & \multicolumn{3}{|c|}{$\begin{array}{l}{[\text { spanname="5to } 7 "] P F} \\
\text { Treatment }\end{array}$} & \multicolumn{3}{|c|}{$\begin{array}{l}\text { [spanname="8to10"] } t \text { - } \\
\text { tests }\end{array}$} \\
\hline & $n$ & Mean & SD & $n$ & Mean & SD & $t$-stat & df & $\begin{array}{l}\text { Sign. } \\
\text { (2- } \\
\text { tailed) }\end{array}$ \\
\hline $\begin{array}{l}\text { Profit } \\
\text { Identification }\end{array}$ & 88 & 1.05 & .209 & 65 & 1.34 & .477 & -5.136 & 151 & .000 \\
\hline $\begin{array}{l}\text { Change in } \\
\text { Profit }\end{array}$ & 68 & 1.07 & .263 & 59 & 1.47 & .504 & -5.730 & 125 & .000 \\
\hline $\begin{array}{l}\text { EPS } \\
\text { Identification }\end{array}$ & 84 & 1.04 & .187 & 64 & 1.47 & .503 & -7.267 & 146 & .000 \\
\hline
\end{tabular}

Table 4 Treatment administered*profit identification

\begin{tabular}{|c|c|c|c|c|}
\hline & & \multicolumn{2}{|c|}{$\begin{array}{l}\text { [spanname="3to } 4 "] \text { Profit } \\
\text { Identification }\end{array}$} & \multirow[b]{2}{*}{ Total } \\
\hline & & $\begin{array}{l}\text { GAAP based } \\
\text { response }\end{array}$ & $\begin{array}{l}\text { Non-GAAP based } \\
\text { response }\end{array}$ & \\
\hline \multirow{3}{*}{$\begin{array}{l}\text { Treatment } \\
\text { administered: }\end{array}$} & GAAP treatment $^{\mathrm{a}}$ & 84 & 4 & 88 \\
\hline & PF treatment ${ }^{\mathrm{b}}$ & 43 & 22 & 65 \\
\hline & & 127 & 26 & 153 \\
\hline \multicolumn{5}{|c|}{ [ spanname="1to5"] Pearson Chi-Square 22.754} \\
\hline \multicolumn{5}{|c|}{ [ spanname="1to5"] Asymp. Sig. (2-sided) .000} \\
\hline
\end{tabular}

${ }^{\mathrm{a}}$ The GAAP treatment case study material consisted of general company information and a GAAP income statement. 
${ }^{b}$ The pro forma treatment case study material consisted of general company information followed by additional pro forma earnings disclosures and a GAAP income statement. The acronym PF treatment is used in reference to this treatment.

Table 5 Treatment administered*change in profit

\begin{tabular}{|l|l|l|l|l|}
\hline & & \multicolumn{2}{|l|}{ [spanname="3to 4"] Change in Profit } & \\
\hline & & $\begin{array}{l}\text { GAAP based } \\
\text { response }\end{array}$ & $\begin{array}{l}\text { Non-GAAP based } \\
\text { response }\end{array}$ & Total \\
\hline $\begin{array}{l}\text { Treatment } \\
\text { administered: }\end{array}$ & GAAP treatment ${ }^{\text {a }}$ & 63 & 5 & 68 \\
\hline & PF treatment ${ }^{\text {b }}$ & 31 & 28 & 59 \\
\hline [spanname="1to5 "] Pearson Chi-Square 26.419 & 94 & 33 & 127 \\
\hline [spanname="1to5 " ] Asymp. Sig. (2-sided) .000
\end{tabular}

${ }^{a}$ The GAAP treatment case study material consisted of general company information and a GAAP income statement.

${ }^{b}$ The pro forma treatment case study material consisted of general company information followed by additional non-GAAP disclosures and a GAAP income statement. The acronym PF treatment is used in reference to this treatment.

Table 6 Treatment administered*EPS identification

\begin{tabular}{|c|c|c|c|c|}
\hline & & \multicolumn{2}{|c|}{$\begin{array}{l}\text { [spanname="3to } 4 "] \text { EPS } \\
\text { Identification }\end{array}$} & \multirow[b]{2}{*}{ Total } \\
\hline & & $\begin{array}{l}\text { GAAP based } \\
\text { response }\end{array}$ & $\begin{array}{l}\text { Non-GAAP based } \\
\text { response }\end{array}$ & \\
\hline \multirow{3}{*}{$\begin{array}{l}\text { Treatment } \\
\text { administered: }\end{array}$} & GAAP treatment $^{a}$ & 81 & 3 & 84 \\
\hline & PF treatment ${ }^{\mathrm{b}}$ & 34 & 30 & 64 \\
\hline & & 115 & 33 & 148 \\
\hline \multicolumn{5}{|c|}{ [spanname="1to5"] Pearson Chi-Square 39.315 } \\
\hline
\end{tabular}

${ }^{a}$ The GAAP treatment case study material consisted of general company information and a GAAP income statement.

${ }^{b}$ The pro forma treatment case study material consisted of general company information followed by additional non-GAAP disclosures and a GAAP income statement. The acronym PF treatment is used in reference to this treatment. 
${ }^{1}$ Pro forma earnings are taken to hold the same or very similar meaning as non-IFRS, nonGAAP, or non-statutory earnings as well as adjusted IFRS, adjusted GAAP or adjusted statutory earnings and are used interchangeably.

2 KPMG's Underlying Profits Report (2011) reports 9\% of companies disclosing non-GAAP earnings on the face of their Income Statement in 2011. ASIC has stated in RG230 (released in December 2011) that financial statements must not include non-GAAP information except 'in the notes to the financial statements in the rare circumstance where such disclosure is necessary to give a true and fair view of the financial position and performance of the entity’ (RG 230.8). The guide explicitly stipulates specific presentations that ASIC believes are inconsistent with AASB101 including the disclosure of non-GAAP earnings as a subtotal or additional line item in the Income Statement or continuing the statement to remove expenses from the GAAP earnings to show non-GAAP earnings.

${ }^{3}$ RG230 provides regulatory guidance explaining when and how ASIC will exercise specific powers under the Corporations Act. Primarily RG230 focuses on requiring non-IFRS financial information not to be presented in the financial statements or the notes to financial statements, except in exceptional circumstances. If non-IFRS financial information is provided in the director's report or another document in the annual report there are guidelines in RG230 to be followed to reduce the risk of non-IFRS financial information being misleading. While this guide does not have the force of law it 'outlines ASIC's interpretation of how to comply with the Corporations Act requirements' for the disclosures of non-GAAP information including non-GAAP earnings (KPMG 2011: 7). Instances of non-compliance that result in misleading nonGAAP disclosures could attract the attention of ASIC and lead to further action being taken by ASIC (KPMG 2011: 7).

${ }^{4}$ The regulatory changes established by the SEC included the creation of Regulation G, amendments to Item 10 of Regulation S-K, and the addition of Item 12 to Form 8-K. Regulation $\mathrm{G}$ required all non-GAAP earnings disclosures to include the most directly comparable GAAP earnings measure, contain a quantitative reconciliation of the nonGAAP earnings measure to that GAAP measure, and not be presented in a way that might mislead investors (Heflin and Hsu 2008). The Regulation S-K (Item 10) amendments prohibit the exclusion of 'non-recurring' items from non-GAAP 
measures included in filings such as 10-Qs and 10-Ks (but not 8-Ks) if those same or similar items are likely to be reported in the previous or following two years (Heflin and Hsu 2008). Form 8-K (Item 12) stipulates that companies must file a Form 8-K within five business days of all annual or quarterly result disclosures and where this includes non-GAAP measures the form must contain the most directly comparable GAAP measure with equal or greater prominence, the reasons why management believes the measure is useful to investors, and a description of how the measure is used by management (Heflin and Hsu 2008).

${ }^{5}$ The difference between sophisticated and non-sophisticated investors is their level of expertise. Koonce and Mercer (2005: 183) define an expert 'as a person who is able to achieve a high level of performance in a particular task or set of tasks'. They refer to 'person- and task-specific factors' outlined in theories of cognitive psychology 'that cause some people to perform better than others'. These features include experience, knowledge and aptitude; 'those with more knowledge and better-organised knowledge tend to perform tasks more quickly’ (p.184).

${ }^{6}$ In addition to the regulatory changes established in the US in 2003 there have been several high profile SEC prosecutions in relation to non-GAAP disclosures made by corporations. For example, Trump Hotels \& Casino Resorts Inc. faced an enforcement action in January 2002 brought by SEC whereby it was charged that 'the company's third-quarter 1999 earnings release was misleading because disclosed earnings included an undisclosed special gain but excluded a special loss' ( 2008). These prosecutions played out in the media and would likely have impacted investor perception of non-GAAP earnings credibility along with their perceptions of the SECs involvement and competence in regulating and managing these disclosures.

${ }^{7}$ According to the Self-Managed Superannuation Fund Statistical Report September 2012 produced by the Australian Taxation Office there were 488576 SMSFs comprising of 932198 members as at 30 September 2012. The assets held by these funds are an estimated \$458 451 million with a total of \$146 926 (or approximately 32\%) invested in domestic (listed and unlisted) and overseas shares. According to the Australian Prudential Regulatory Authority March 2012 Quarterly Superannuation Performance report, as 'at 31 March 2012, self-managed superannuation funds held the largest proportion of superannuation assets accounting for 30.3 per cent of assets'. The 
chairman of ASIC, Greg Medcraft, 'has highlighted the growth of self-managed super funds as the greatest challenge facing the regulator in the next decade' (White, 2013.)

${ }^{8}$ The experiment is available upon request from the authors.

${ }^{9}$ Allee et al. (2007) employ an empirical proxy for investor sophistication. They rely on trade size based proxies to differentiate between wealthy, institutional investors (represented by large trades) and less-wealthy, individual investors (represented by small trades).

${ }^{10}$ Zhang and Zheng (2011) quantify reconciliation quality into four categories assigning ordinal measures to each category. Companies that included a table explicitly reconciling non-GAAP earnings with GAAP earnings were assigned the highest reconciliation quality score, due to the ease of comparison that this format allows.

${ }^{11}$ Not all participants provided a response to all three questions; therefore, the sample size in Table $\underline{3}$ varies between the three key variables. The participant response rates for the GAAP treatment was 100\% for Profit Identification, $77.27 \%$ for Change in Profit and 95.45\% for EPS Identification. The participant response rates for the PF treatment was 95.58\% for Profit Identification, 86.7\% for Change in Profit and 94.11\% for EPS Identification.

${ }^{12}$ A very small number of GAAP treatment participants were unable to correctly identify basic GAAP based information from the information presented. These incorrect responses where coded as '2' or non-GAAP based response. As a result the mean coded value of the GAAP treatment participants’ responses is slightly higher than the expected value of 1 . 